ISSN 2078-6441. Вісник Львівського університету. Серія географічна. 2013. Випуск 44. С. 71-79. Visnyk of the Lviv University. Series Geography. 2013. Issue 44. P. 71-79.

504.53: $631.445 .42(477.54)$

\author{
(до створення ервоної книги грунтів) \\ икол орін, ригорій льховський
}

рківський н ціон льний гр рний університет імені . . окуч єв , n/в омуніст-1, 62483, м. рків, кр їн, e-mail:office@knau.kharkov.ua; lukogor@gmail.com

\begin{abstract}
ведено ретроспективні результ ти еогр фічної мережі дослідів з добрив ми н дослідному полі рківського гроуніверситету т пропозиції щодо з повід ння високобонітетних в рі нтів грочорноземів т інших рідкісних і зник ючих грунтів до ервоної книги грунтів.

лючові слов : еогр фічн мереж дослідів, добрив , чорнозем, цілинні т гроземні грунти, ервон книг грунтів, моніторинг, природно-з повідний фонд.
\end{abstract}

н слідок розп юв ння н прикінці ст. колгоспів і р дгоспів, кр їн зробил рішучий крок до ринку земель і водноч с зіткнул сь з погіршенням екологічного ст ну грунтово-земельного ресурсу, яке, як не п р докс льно, збіглося с ме 3 періодом реформув ння земельних відносин, торкнувшись передусім земель сільськогоспод рського призн чення, тобто 42 млн з 60,4 млн г укр їнських земель, більше 23 млн г яких предст влено чорнозем ми. к н л годити декв тний онституції кр їни, емельному т іншим кодекс м контроль 3 різном нітними і дин мічними екологічними ситу ціями, щоби вторгнення юдини в довкілля, зокрем грунтове, д в ло суспільству м ксимум користі т мінімум шкоди? умови, що головною причиною з гострення дефіциту родючих грунтів в кр їні 3 iї чорноземними ет лон ми біосферної родючості виявилося призупинення держ вних прогр м 3 охорони т підвищення родючості грунтів.

ошук відповідей н ці прості й водноч с проблемні пит ння пов'яз ний, як свідч ть літер турні джерел [1-10], з певними труднощ ми в отрим нні грунтовоекологічної інформ ції, прогнозув нні т прийнятті упр влінських рішень у г лузі відтворення (підвищення) родючості грунтів н б зі р ціон льного, культурного, х зяйновитого господ рюв ння н землі, яким, поз сумнівом, є екологічно орієнтов не грохімічне окультурюв ння грунтів як 3 г лом, т к і в меж х конкретного землекористув ч . прикл д, т кого, як н вч льно-дослідне господ рство рківського гроуніверситету “ окуч євське” з його чорнозем ми типовими, які . окуч єв з довго до сьогоднішнього “земельного дериб ну” порівняв з чистокровним р бським ск куном, з гн ним до піни невмілим вершником.

це 3 умови, що існує 3 тверджений з дорученням бінету іністрів кр їни “ ерелік особливо цінних грунтів”, серед яких н зв но й чорноземи типові. . едведєв i . лімов виділяють (згідно з концепцією охорони грунтової різном нітності) типові, рідкісні, зник ючі, р ритетні т інші охоронні к тегорії грунтів, рекомендуючи уточнюв ти і дет лізув ти їх у процесі регіон льного моніторингу з ур хув н-

(C) орін ., льховський ., 2013 
ням ф ці льних т інших особливостей [6]. прикл д, чорноземи н схил х (зокрем , чорноземи короткопрофільні н лесових пород х, підстелених червоно-бурими глин ми) вони вв ж ють рідкісними і н віть р ритетними грунт ми. г лом же чорноземи є зник ючим типом грунтів, який (поряд з торфовищ ми) пропонують з носити до попередніх списків ще не створеної ервоної книги грунтів.

зн чимо, що в земельному м сиві н вч льного господ рств “ окуч євське” (колишній “ омуніст”), крім головного ог нського ст ціон ру, є ослідне поле площею 40 г у шостому полі колишньої з хідної сівозміни, де в 70-90-х рок х ст. “проводили полевые опыты по схем м еогр фической сети опытов с удобрениями в учебно-опытном хозяйстве “ оммунист" рьковского с.-х. институт имени . . окуч ев н мощном среднегумусном тяжелосуглинистом чернозёме” $[4,5,8]$. роки існув ння еомережі тут було сформов но високобонітетні окультурені в рі нти грочорноземів ( . ихоненко) як ет лонів родючості в скл ді моніторингових полігонів, дедосліджують їхній екологічний ст н і прогнозують н прям еволюції грунтових екофункцій (передусім родючості) для розробки упр влінських рішень 3 р ціон льного використ ння земель.

ослідному полі з прогр мою еогр фічної мережсі дослідів з добрив ми доведено, що “минер льные удобрения $\mathrm{N}_{60} \mathrm{P}_{40} \mathrm{~K}_{30}$ при внесении под озимую пшеницу по неп ровым предшественник м обеспечив ли в среднем з 15 лет повышение урож йности н 35-50\%, з 10 лет с 1975 по 1985 г. - н 44-66 \% при урож е н контроле 30 ц/г ; н зв нные дозы были призн ны оптим льными под озимую пшеницу для д нных условий н основ нии опытов оссети" [7]. озитивний вплив мінер льних добрив н якість зерн головної продовольчої культури - пшениці - підтверджено достовірним підвищенням порівняно з неудобреним контролем у 2,5 p 3 вмісту білк і н $\quad 0,8-2,7 \%$ клейковини. несення добрив в оптим льно-мінім льних доз х $(\mathrm{NPK})_{45}$ з безпечув ло отрим ння з 1 г м йже 50 р дянських рублів чистого доходу з рівня господ рської рент бельності $200 \%$ (внесення добрив у вдвічі вищих доз х $(\mathrm{NPK})_{90}$ дещо зменшув ло чистий дохід і рівень рент бельності - до $80 \%$ зі збереженням тенденції до підвищення врож йності зерн пшениці н цих в рі нт х). умов кл сичних дослідів еогр фічної мережі з'ясов но, що добрив м йже не порушув ли співвідношення між головними елемент ми живлення - н корені прип д є 15-21\% поглинутого зоту, 10-15 фосфору і 7-9 \% к лію. врож ю зерн 54 ц/г біологічн потреб рослин пшениці в зоті дорівнюв л $203 \mathrm{Kг,} 25-48,2-212$ кг.

фіксов но відмінності в н копиченні хімічних елементів у зерні порівняно 3 порядком їхнього поглин ння вегет тивними орг н ми пшениці т вмісту у грунті. иявлено одн кову послідовність кількості спожитих біогенних елементів у зерні пшениці, вирощеній н двох поживних фон х - голодному контролі т грохімічно окультуреному (NPK) грочорноземі. гній посів перше місце, к льцій - друге.

ступні місця з йняли, відповідно, м нг н, з лізо, цинк. ідь поступил ся місцем люмінію (не виключено, потрібному зл к м). осьме й дев'яте місця посіли стронцій і нікель (можливо, т кож біогенні мікроелементи), ост нні чотири місця - в жкі мет ли: відповідно, хром, свинець, коб льт і к дмій. них коб льт є мікроелементом, інші в жкі мет ли входять до групи небезпечних з бруднюв чів грунтів, продовольчої продукції, біосфери з г лом. иявлені у продовольчому зерні озимої пшениці їхні мінім льні концентр ції н д ють підст ви для високих оцінок екологічної безпечності пшеничної продукції, вирощеної н різних грохімічних фон х грочорнозему типового, удобрюв ного мінер льними добрив ми $[2,8]$. 
“ то мы имеем н сегодняшний день?”- з питує к демік . інеєв, який 3 1972 р. очолюв в еогр фічну мережу дослідів з добрив ми, і відповід є: “ 1985 . ост новлен ре лиз ции прогр ммы исследов ний в еосети. рушены н учные творческие связи с учёными регионов, которые уст новил . . рянишников в 20-х год х прошлого столетия. очти полностью ликвидиров н сеть грохимических н учных учреждений в системе , вуз х и н учных учреждениях - это, по существу, их ликвид ция. опущен огромн я ошибк в н учном обеспечении отечественного земледелия. сли счит ть, что человечество н емле пит ется н $95 \%$ продукт ми, полученными 3 счёт плодородия почвы, удобрения есть н иболее быстродействующий и эффективный путь его воспроизводств, то и грохимия з служив ет соответствующего к ней вним ния. то же дел ть сейч с и в ближ йшей перспективе? режде всего р звив ть творческое н учное сотрудничество учёных грохимиков, объединяясь вокруг гл вного координ тор ... исследов ний по грохимии, гроэкологии, почвоведению, ст р ясь достичь былой сл вы грохимической н уки и решить её фунд мент льные и пр ктические проблемы” [7].

и умисно процитув ли к демік . інеєв , щоб усвідомити спільність 3 вд нь, які стоять перед н уковцями і пр ктик ми гр рного виробництв в осії, кр їні т інших держ в х-член $\mathrm{x} \quad$, 3 огляду н ту обст вину, що еогр фічн мереж дослідів 3 добрив ми бул н той ч с всесоюзною і, зв ж ючи н ії геогр фічність, ніщо не $з$ в ж $є$ повернути їй цей ст тус уже в чинних р мк х з конод вчого поля

е в період з 1926 по 1930 рр. $з$ єдиною прогр мою під керівництвом . рянишніков i . ебедянцев було пост влено близько 4000 дослідів у різних грунтовобіоклім тичних зон х . м еогр фічн мереж дослідів з добрив ми створен у 1941 p. рг ніз тором і керівником робіт еомережі до 1969 р. учень і сор тник . рянишніков, професор . йдін, з 1972 p. еомережу дослідів очолив інеєєв. одішня інвент риз ція виявил у еомережі пон д 660 б г торічних ст ціон рних дослідів, для яких скл дено схеми б г торічних дослідів з ур хув нням особливостей грунтово-біоклім тичних умов різних землеробських регіонів дянського оюзу. період 1972-1985 pр. $з$ кл д ми еомережі вид но для всіх природноекономічних регіонів (у тім числі й для кр їни) “ укові основи і рекоменд ції по з стосув нню добрив”, ктивну уч сть у розробці яких бр ли . вдонін, . ореньков, . ул ковськ, . оско т б г то інших, зокрем укр їнських вторів.

1975 р. еомереж н лічув л 297 н укових 3 кл дів, з них 114,113 дослідних ст нцій і 70 сільськогоспод рських вузів, у тім числі й рківський ім. . окуч єв 3 ослідним полем н чорноземі типовому $[4,5,8]$. еличезну роботу виконув л рогр мно-методичн комісія еогр фічної мережі під керівництвом віце-президент . нніков , орг ніз тор всесоюзних н р д еомережі, у яких бр ли уч сть й втори дослідів еомережі н ослідному полі підст ві експеримент льних д них еомережі, дослідів 3 добрив ми розроблено і перед но держ вним орг н м т кі н дзвич йно в жливі м тері ли, як “отреб сільського господ рств в мінер льних добрив х н 1990 p, їх оптим льний сортимент т якість”, “ гроекономічне обгрунтув ння сортименту т якості мінер льних добрив в до 2000 р.”, “ омплексн к рт геолого-економічної оцінки ресурсів грохімічної сировини в ( п тити, фосфорити, к лійні солі)” $з$ пояснюв льною з пискою до неї. д ними еомережі вперше розроблено норм тиви з тр т мінер льних добрив, хімічних меліор нтів, мікродобрив т гною н отрим ння 1 т сільгосппродукції. еогр фічн мереж дослідів 3 добрив ми перебув л під 
Пильною ув гою

, яке постійно дб ло про розширення, розвиток т високим через фунд мент льні н пр цюв ння уч сників дослідів з добрив ми [7].

ведені ф кти є досить в гомими ргумент ми, які спонук ють зг дув ти сьогодні м йже легенд рну еогр фічну мережу дослідів з добрив ми, до якої були причетні й н уковці рківського (нині ім. . . окуч єв). инішню ситу цію 3 орними чорнозем ми відобр ж ють прикл ди нез конного використ ння земель

рківського гроуніверситету некв ліфіков ними сторонніми особ ми, н слідки якого $\epsilon$ дегр д ційними. гнорув ння н уково обгрунтов ної системи землеробств призвело до ктивіз ції процесів екоцидного спрямув ння, зокрем, й дегр д ції грунтів, зниження їхньої родючості, високий рівень якої з безпечув ли з стосув нням донед вн рекомендов них еомережею добрив, отже, й отрим ння високих, головне ст більних врож їв вирощув них сільськогоспод рських рослин.

н слідок некв ліфіков ного землегоспод рюв ння ост нніми рок ми повністю зруйнов но систему сівозмін (польових, грунтоз хисних, кормових, овочевих), як бездог нно функціонув л десятк ми років для підвищення родючості грунтів т врож йності вирощув них рослин. іквід ція тв ринницького цеху позб вил грунти впливу угноєння, як і впливу бобових тр востоїв (т інших предст вників бобових сої, кв солі, нуту, гороху, чини), відповідно до розробленої ф хівцями н уковообгрунтов ної системи добрив. к систем донед вн протидіял дегр д ційним процес м дегуміфік ції і зменшенню кількості доступних рослин м поживних речовин (N, P, K, Ca, Mg, S, мікроелементів) у чорноземних ет лон х біосферної родючості, підвищув л їхню біологічну ктивність, сприял формув нню грономічно (з г лом екологічно) цінної зернистої структури. нищення поголів'я те ліквід ція гнойового господ рств призвел до дегр д ції грунтів н вч льного господ рств і спричинил зниження їхньої родючості. е використовують 3 призн ченням природні угіддя, які ст більно з безпечув ли н дходження якісних зелених кормів і сін до тв ринницького цеху. гнорув ння н уково обгрунтов ною системою землеробств пост вило його н ту гр нь, 3 якою почин ються незворотні екоцидні процеси дегр д ції грунтів і зниження їхньої родючості.

н шу думку, нем є іншої льтерн тиви, як підтрим ти творчу ініці тиву грохіміків, гроекологів т грунтозн вців осії щодо відродження н турних експериментів 3 грохімічного окультурюв ння грочорноземів типових, у тім числі й н ослідному nолi колишньої еогр фічної мережі дослідів 3 добрив ми, спрямов ного н вирішення держ вницьких 3 зн чимістю, фунд мент льних т пр гм тичних грунтозн вчо- грохімічних т екологічних проблем, зокрем н фунд цію ервоної книги грунтів.

творення ервоної книги грунтів т пї пр вове 3 твердження н різних рівнях (держ вному, регіон льному, обл сному) м є, н думку . обровольського [3], принципове зн чення для ре ліз ції особливої охорони грунтів і біосфери з г лом. ей документ не тільки створить юридичні підв лини для збереження грунтової різном нітності, й систем тизує с м процес збереження “четвертого ц рств природи" ( . окуч єв), тобто їі грунтового покриву як геодерми пл нети. ез т кого пр вового документ спроби зберегти природно-історичні грунтові тіл не д дуть н лежного ефекту і виявляться м рними.

ервоні книги, як документи виняткової в жливості, вміщують відомості про різні природні об’єКти, що підляг ють особливій охороні 3 огляду н ре льну 3 грозу 
їхнього зникнення бо сильної дегр д ції. онед вн т кими були лише ервоні книги рослин і тв рин. ервоні ж книги зник ючих екосистем т їхніх грунтових компонентів перебув ють н р зі в ст дії розробки і створені лише в окремих суб'єкт х осійської едер ції [3]. хня відсутність в кр їні суттєво г льмує збереження цих унік льних “витворів" природи, не з хищених у н шій держ ві спеці льною грунтоохоронною гр мотою. днією 3 причин т кого г льмув ння $€$ недост тнє усвідомлення н держ вному рівні екологічної зн чущості існув ння н пл неті емля всіх дітищ іiі еволюційного розвитку.

ля того, щоб зберегти

як унік льну екосистему пл нети, потрібно повсякч с піклув тися про їі трофічний фунд мент, с ме - всю розм їтість природних грунтових утворень, з яких до ервоної книги треб нег йно включити передусім ті, які перебув ють під з грозою зникнення. одноч с це посприяє успішному вирішенню 6 г тьох суто пр ктичних з вд нь. прикл д, для моніторингу якості грунтів і порівняльного н лізу процесів грунтогенезу, що відбув ються в цілинних т освоєних землях, н думку - едведєв , обов'язково потрібно м ти ет лонні грунти [6]. е підляг є сумніву ксіом щодо перебув ння окультурюв них ( гроземних . ихоненко) грунтів у полоні природних чинників грунтогенезу, очевидно, скорегов них господ рською діяльністю людини. ож, моніторинг змін в грозем х $[9,10]$, спровоков них людиною н тлі природних процесів, є конче потрібним для розробки оптим льних систем землеробств, екологічно орієнтов них н м ксим льне використ ння ресурсного потенці лу грунтової родючості, який сформов но природними грунтотворними чинник ми, тепер не може бути поновлений без пр ці людей.

риродн ж родючість грунту з умови пр вильного поводження з нею може зберіг тися н дост тньо високому рівні впродовж дуже трив лого ч су. е доведено дослід ми от мстедської ст нції, н йст рішої в кр їні (з г лом н терен х ) олт вської т інших дослідних ст нцій, т кож у еогр фічній мережі дослідів 3 добрив ми $[4,5,7,8]$. звич й же, потенційну родючість грунтів у більшості гровиробничих ситу цій використовують неефективно, то й повністю блокують.

едооцінку ресурсного екопотенці лу природної грунтової родючості 6 г то в чому пояснюють м йже повною відсутністю декв тної грунтово-екологічної інформ ції, достовірність якої зн чно знижується через обмеженість порівнянь гроземів 3 ет лонними цілинними грунт ми, які в чорноземній зоні тепу т ісостепу м йже не збереглися $[6,9,10]$.

езз перечн теоретичн й пр ктичн користь від з повід ння рідкісних, р ритетних т подібних грунтів, т кож екологічно доцільне оптим льне чергув ння оброблюв них ( гроземних) і цілинних (т перелогових) грунтів підтверджені передусім тим, що цілинні виконують біосферно зн чиму екофункцію пост ч льників корисних мікроорг нізмів і безхребетних тв рин, які постійно гинуть н сільськогоспод рських л н х через перевищення міри нтропотехногенних н в нт жень н гроземи [10].

і т інші не менш переконливі ргументи н користь нег йного створення ервоної книги грунтів, одн к, виклик ють і з перечення - мовляв, у 3 повідник х уже 3 повід но й відповідні грунти. к з зн ч $є$. обровольський [3], це спр вді т к, ле ж ті грунти (які спр вді треб неодмінно зберегти) є лише дефр гментов ною ч сткою зн чно ширшого їх розм їття. ричин неповноти й дефр гментов ності списку грунтів, які треб з повід ти, прихов н в тому, що перев жну ч стину з повідних територій виділяли для з хисту рослин і тв рин, грунти з повід ли втом тично, оскільки вони виконув ли екологічну функцію житл , депо з родків життя, поживних 
елементів, води тощо. ерез це б г то зник ючих грунтів до екомережі з повідників, з к зників, п м'яток природи, н ціон льних і л ндш фтних п рків, біосферних резерв тів не потр пили і не могли потр пити, бо їх не було внесено до н явних ервоних книг. це 3 умови, що від якісного (повного, системного) 3 повід ння грунтових компонентів л ндш фтних, біогеоценотичних т інших екосистем ф ктично з лежить вирішення всієї природоохоронної проблем тики. ому т к кту льн сьогодні проблем грунтового з повід ння в системі довготермінових з ходів щодо розвитку екологічної мережі територій, яким н д но ст тус особливої охорони.

ж ль, ця проблем пост влен порівняно нед вно. р дянській н уковій літер турі ідею створення ервоної книги грунтів висловлюв ли грунтозн вці з 1979 р. ( . обровольський, . ікітін). жливі спекти цієї проблеми, 3 свідченням . обровольського, висвітлили . рупеніков, . рп чевський, в кр їні едведєв, . лімов т ін. [6]. ля розробки ервоної книги грунтів зг д ні втори вв ж ють 3 доцільне використ ти досвід створення ервоних книг рослин і тв рин. роте повн н логія тут неможлив , 3 огляду н відому специфічність природних грунтових утворень (різном нітність, композиційн моз їчність, дин мічність) і коригув льний вплив н них людини.

ому необхідне визн чення тих грунтів, що підляг ють вищим форм м охорони з огляду н три к тегорї̈ грунтових утворень: цілинні (природні) грунти, нтропогенно освоєні грунти, окультурені грунти (н були суттєво вищої родючості з вдяки р ціон льному землегоспод рюв нню). о ервоної книги можн включ ти будь-які грунти з цих к тегорій, одн к цілі й форми їхньої охорони можуть суттєво відрізнятися. ерез це, крім рідкісних і зник ючих цілинних грунтів, режим особливої охорони можн 3 пров дити і для репрезент тивних ет лонів н йбільш поширених грунтів з метою усунення небезпеки їхнього безконтрольного освоєння т орг ніз ції нех й з пізнілого, проте всебічного грунтового моніторингу як скл дової ч стини екологічного моніторингу ( . едведєв).

оловними форм ми охорони цілинних грунтів можуть бути суто грунтові з повідники і з повідники спеці льного режиму, н території яких допуск ють лише т кі дії, що не м ють помітного впливу н природний грунтогенез т його чинники (полюв ння, помірне збир ння ягід, грибів, лік рських рослин; з готівля лучних тр в кормового призн чення; розведення бджіл тощо). р зі включення до ервоної книги освоєних грунтів ( гроземів) необхідно виявити н йменш змінені їхні відмінності, екофункціон льно н ближені до цілинних ет лонів (через що вони й потребують охорони). огляду н зн чне нтропогенне перетворення природного середовищ 6 г то грунтів з лишилися без цілинних ет лонів. орноземи ж уз г лі опинилися букв льно в дегр д ційному полоні, оскільки освоєння європейських регіонів їхнього поширення ( ісостеп і теп) д вно перевищило екологічний оптимум. це при тому, що повне землеробське освоєння будь-якої $л$ ндш фтної екосистеми гр нично мінімізує (до $25 \%$ від можливого м ксимуму) отрим ння корисної біопродукції ( . еймерс).

к 3 не н д $є$ виняткової пр ктичної і н укової зн чимості переведенню ч стини освоєних земель у режим особливої охорони. ке з вд ння потрібно невідкл дно вирішити, дже освоєні землі з кожним роком не просто сильно змінюються - вони дегр дують (під впливом ерозії, дефляції, технохемогенного з бруднення, видобутку корисних коп лин тощо). йбільш доцільною і поширеною формою охорони освоєних (гроземних) грунтів (у р зі їх включення до ервоної книги) . обровольський ув ж є орг ніз цію грунтових з повідників 3 г льного режиму 3 
т кою регл мент цією: н території грунтових з повідників з боронене м сшт бне будівництво промислових, побутових і житлових об'єктів; 3 ходи з хисту грунтів (з г лом екосистем) від з бруднення вжив ють у повному обсязі; вирощув ння сільськогоспод рських культур допустиме лише з дотрим нням усіх з ходів, що протидіють дегр д ції грунтів.

окремих ділянк х з мінім льно зміненими грозем ми є сенс формув ти грунтові з к зники $і$ з повідники спеці льного режиму для з безпечення необхідної репрезент тивності ет лонних грунтів, що г р нтов не с ме $н$ дійністю їхнього зберіг ння в т ких з к зник х. ерез це н першому ет пі доцільно орг нізовув ти у господ рств $\mathrm{x}$ будь-якої форми вл сності н землю хоч 6 невеликі 3 площею грунтові $3 \kappa$ зники і 3 повідники. ж ль, повного н укового огляду з цього пит ння ще нем . е пояснюють тим, що д леко не всі грунти територій вивчені з необхідною повнотою (н дійно ді гностов ні, кл сифіков ні, оцінені тощо). тже, н г льною необхідністю ст є створення повного номенкл турного списку вже з повід них грунтів. ля цього . едвєдєв рекомендує терміново з пров джув ти з мість недоскон лого земельного К д стру грунтовий моніторинг; без цього под льш розробк ервоної книги грунтів зн чно з Г льмується. ля розуміння зн чимості збереження т охорони "четвертого ц рств природи” особливо в жливим є вчення про нез мінність грунтового покриву в іосфері, унік льність т екологічну поліфункціон льність грунтового покриву пл нети ( . обровольський).

тже, н голосимо, що проблеми охорони грунтів і р ціон льного землегоспод рюв ння, включ ючи створення ервоної книги грунтів, виходять д леко з межі суто грунтоз хисних з вд нь - вони перерост ють у проблеми ст більного функціонув ння іосфери з г лом, оскільки біогеоценотичні і глоб льні екофункції грунтів (передусім, природних) є г р нтом збереження еволюційно з д них кругообігів біогенних елементів і енергії н емлі (без цього життя неможливе). ож є сенс $з$ пров джув ти грунтово-екологічний моніторинг природного т гроземного (3 . ихоненком) грунтогенезу в долинно-л ндш фтних, біогеоценотичних т інших екосистем х, у тім числі н землях н вч льного господ рств “ окуч євське” т прилеглих господ рств, де ми пропонуємо створити регіон льний $л$ ндш фтний $n$ рк“ ог нський” з екологічно орієнтов ним землегоспод рюв нням, розпоч вши скл д ння номенкл турного списку для ервоної книги грунтів с ме з цієї території, зокрем , з її дослідних (моніторингових) полігонів, у тім числі й тих, що н леж ли колись до еогр фічної мережі дослідів з добрив ми, які конче необхідно рест врув ти.

\section{СПИСОК ВИКОРИСТАНОЇ ЛІТЕРАТУРИ}

1. орін . . пл вний грунтогенез т його фіто грохімічн корекція / . орін // грохімія і грунтозн вство (до VII з'їзду , липень 2006 р., м. иїв). - ., 2006. - н. 2. - .39-41.

2. орін . . імізм озимої пшениці т лучних тр востоїв кормового призн чення при грохімічному окультурюв нні грунтів (екологічний спект) / . . орін, . . льховський // існик . - ., 2009. - № 3. - . 115-126.

3. обровольский . . кология почв / . . обровольский, . . икитин. - . : зд-во , 2006. -476 с. 
4. лизовский . . ействие минер льных удобрений н урож йность озимой пшеницы в условиях евобережной есостепи $/$. . лизовский, . . льховский, . . . ырый // грохимия. - 1980. - № 10. - . 53-58.

5. лизовский . . ценк эффективности минер льных удобрений при внесении под озимую пшеницу н чернозёме типичном и з висимость их действия от погодных условий / . . . лизовский, . . льховский // грохимия. - 1980. - № 5. $.51-58$.

6. едведєв . . ипові, рідкісні т зник ючі види грунтів кр їни / . . едведєв, . . одоб , . . лімов // грохімія і грунтозн вство. - 1998. - ип. 59. . 13-27.

7. инеев . . н чение геогр фической сети опытов с удобрениями в решении кту льных проблем грохимии / [ лектронный ресурc] / http://www.geoset.ru/data/files/znachenie.pdf.

8. льховский . . иологический вынос зот, фосфор и к лия озимой пшеницей н р зноудобренных фон х / . . льховский // грохимия. - 1980. - № 7. - . 54-58.

9. ихоненко . . рунти долинних екосистем івобережного ісостепу кр їни (н уковий доробок окуч євської к федри грунтозн вств ) / . . ихоненко, . . орін, . . егтярьов // грохімія і грунтозн вство. пеці льний випуск до VIII з'їзду (5-9 липня 2010 р., м. итомир). - ., 2010. - . 151-163.

10. ихоненко . . волюція грогенних грунтів кр їни / . . ихоненко // уч сне грунтозн вство: н укові проблеми т методологія викл д ння: м тері ли міжн родної н уково-пр ктичної конференції, присвяченої 90-річчю к федри грунтозн вств т охорони грунтів імені професор . . икули. - ., 2012. - . 290-292.

$$
\begin{gathered}
m \text { ття:н дійшл до ред кцї̈ 12.03.2013 } \\
\text { доопр иьов н 16.04.2013 } \\
\text { прийнят до друку 17.06.2013 }
\end{gathered}
$$

\title{
GEONETWORK EXPERIENCES ON ROGAN STATIONARY EXPERIMENTAL FIELD AND PROBLEM OF ESTABLISHING RESERVATIONS OF CHERNOSEM (for creating the Red Book of soils)
}

\author{
Mykola Gorin, Grigoriy Olkhovskyi \\ V. Dokuchaev Kharkiv National Agrarian University, \\ p/o Kommunist-1, UA - 62483, Kharkiv, Ukraine, \\ e-mail: office@knau.kharkov.ua; lukogor@gmail.com
}

Retrospective results of the Geographic networke experiments with fertilizers on the experimental field of Kharkiv Agrarian University have been described and proposals on entering variants of agrochernozems of high bonitet along with vanishing and uncommon soils into the Red Book of soils are given.

Key words: Geographic network of experiments, fertilizers, chernozems (black earth), virgin lands and agrozems, Red Book of soils, monitoring, nature conservation fund. 


\section{(к созд нию р сной книги почв)}

\section{иколй орин, ригорий льховський}

рьковский н цион льный гр рный университет имени . . окуч ев , n/о оммунист-1, 62483, г. рьков, кр ин,

e-mail: office@knau.kharkov.ua; lukogor@gmail.com

пис но ретроспективные результ ты еогр фической сети опытов с удобрениями н опытном поле рьковского гроуниверситет и д но предложения о внесении высокобонитетных в ри нтов грочернозёмов вместе с исчез ющими и редкостными почв ми в р сную книгу почв.

лючевые слов : еогр фическ я сеть опытов, удобрения, чернозём, целинные и грозёмные почвы, р сн я книг почв, мониторинг, природно-з поведный фонд. 